\title{
Compensation and Work Culture on Organizational Performance with in mediation by Work Satisfaction in Fire Department Service of Sungai Penuh City
}

\author{
Syamsudirman \\ Master of Management Study Program \\ Institute of Economic Science, Finance, Banking and Development Padang
}

Hendra Yurmain

Lecturer in Management Master Program, School of Finance and Banking (STIE "KBP"), JL Khatib Sulaiman No. 61 Lolong Belanti, Padang Utara 25136, West Sumatra, Indonesia

\section{Heryanto}

Chair of the Management Master Program, School of Finance and Banking (STIE "KBP"), JL Khatib Sulaiman No. 61 Lolong Belanti, Padang Utara 25136, West Sumatra, Indonesia

\begin{abstract}
This study aims to examine the effect of compensation and work culture on organizational performance by mediating work satisfaction on Fire Department and Rescue of Sungai Penuh City. This research is motivated by the fact that Compensation, Work Culture and Job Satisfaction influence Organizational Performance. The independent variables in this study are Compensation, Work Culture and Job Satisfaction. The dependent variable in this study is the Organizational Performance of the Fire Department and Rescue of Sungai Penuh City. The data in this study are primary data obtained from questionnaires distributed directly to respondents. Data collected from 162 respondents, which are Operational Staff of the Fire Department and Rescue of Sungai Penuh City. The hypothesis in this study was tested using path analysis. From the results of data analysis using path analysis, it is known that the Compensation $\left(\mathrm{X}_{1}\right)$ and Work Culture $\left(\mathrm{X}_{2}\right)$ variables have a positive and significant effect on Job Satisfaction $\left(X_{3}\right)$ and Compensation $\left(X_{1}\right)$, Work Culture $\left(X_{2}\right)$ and Job Satisfaction $\left(\mathrm{X}_{3}\right)$. Significantly on the organizational performance of the Sungai Penuh City Fire and Rescue Service (Y).The results of this study prove that Compensation, Work Culture and Job Satisfaction affect the Organizational Performance of the Fire Department and Rescue of Sungai Penuh City. The performance of the Sungai Penuh City Fire and Rescue Service will increase if the compensation provided is in accordance with the work performed.
\end{abstract}

Keywords: Compensation, Work Culture, Job Satisfaction,Performance

\section{INTRODUCTION}

Sungai Penuh City is an expansion area of Kerinci Regency which was formed based on Law number 25 of 2008. The development of an urban area has brought an important problem such as the swift flow of population mobilization from village to city and the development of various residential, industrial and trade areas. One of the effects of these conditions is a threat to fire hazards. Lately, fire events often occur in the community. Fires that occur in densely populated settlements, especially in industrial estate areas can cause many losses, including losses due to social, economic and psychological.

Fires in industrial estates can result in cessation of business and investment losses that have an impact on termination of employment. Meanwhile, demands for salvation against fire and 
other urban disasters are increasing along with the increasing incidence of disasters. Not all regions have regulations regarding the technical prevention and control of fire hazards. The aspect of fire protection has not been considered as one of the basic needs. As a result, the incidence of fire is often fatal and repetitive.

The Fire Department Service is a Government agency that specializes in handling and preventing fires. That is expected to be able to overcome, prevent and cope with the occurrence of fires in Sungai Penuh City. The tasks carried out by the Sungai Penuh City Fire Department Service have not run smoothly with what was expected by the community. The main task of the Fire Department Service is to help the Mayor of Sungai Penuh in carrying out regional authority in the field of fire prevention and the function of the Fire Department Service, namely formulating technical policies in the field of fire prevention and control, carrying out operational technical tasks in the field of fire prevention and management. administrative techniques include general administration and staffing, planning and development and financial administration.

During 2013-2017 in Sungai Penuh City there were various problems that existed in the Sungai Penuh City Fire and Rescue Service as there was still a lack of socialization to the community which included the introduction, guidance and counseling to the community, government and private institutions regarding prevention and control of fire extinguishers. The direct implementer of the fire fighting process that occurred at the fire location was Operational Staff, for the City of Sungai Penuh the number of Operational Officers who were prepared when the fire disaster in 2018 amounted to 273 people divided into 6 platoon. The large number of Operational Executors for firefighters is not accompanied by an increase in salaries of Operational Staff. Operational Status of the Sungai Penuh City Fire Department which is a temporary employee earns a salary of between Rp.400,000 - Rp. 800,000 per month. This is certainly not proportional to the work risk that is obtained even though the average level of education of Operational Workers ends in junior high and high school.

Limitations on facilities and infrastructure of the Fire Department so that they are not supported by adequate equipment. This is an obstacle for the Sungai Penuh City Fire and Rescue Service. Where the Fire Department only has 6 units of fire engines which are divided into 5 fire stations, 4 fire car units are in each of the aid posts and 2 fire cars are in the center of Sungai Penuh City Post. But basically for 8 sub-districts in Sungai Penuh City, the Sungai Penuh City Fire Department should have at least 15 fire engines to support the implementation of fire suppression.

Every time a fire that occurred in Sungai Penuh City, it became a great fire and a large amount. This is certainly worthy of being an evaluation of the Sungai Penuh City Government, especially regarding fleets and fire fighting equipment. There are 5 units of the fire department but they are damaged 2, the size of the car is small and the hose is short and the officers are not available such as clothes and other equipment. Related to this, it needs to be evaluated in the future, especially regarding fire trucks and supporting equipment for officers.

Still slow time taken by the fire truck to the location of the fire that should be 15 minutes response time. If there is a fire case, the Fire Department officers have difficulty getting to the location because the fire station is far from the location of the incident and the location of the fire is densely populated, so the travel time arrives at the location of the incident more than 15 minutes. Furthermore, their work is considered slow and unprofessional. To improve the performance of the Sungai Penuh City Fire and Rescue Service, it is necessary to conduct an evaluation within the Sungai Penuh City Fire and Rescue Service organization. For that various 
problems that occur become something that must be considered to improve performance as follow:

1. What is the effect of compensation on the work culture of the Sungai Penuh City Fire and Rescue Service?

2. What is the effect of compensation on the job satisfaction of the Sungai Penuh City Fire and Rescue Service?

3. What is the effect of work culture on the job satisfaction of the Sungai Penuh City Fire and Rescue Service?

4. What is the effect of job satisfaction on the performance of the Sungai Penuh City Fire and Rescue Service?

5. What is the effect of compensation on the performance of the Sungai Penuh City Fire and Rescue Service?

6. What is the effect of compensation on the performance of the Sungai Penuh City Fire and Rescue Service?

7. What is the effect of work culture on the performance of the Sungai Penuh City Fire and Rescue Service?

8. What is the effect of compensation and work culture on performance mediated by job satisfaction at the Sungai Penuh City Fire and Rescue Service?

\section{Compensation}

\section{THEORITICAL REVIEW}

Compensation is one of the important functions in human resource management. Because compensation is one of the most sensitive aspects of a work relationship. Cases that occur in employment relationships contain compensation problems and various related aspects, such as benefits, compensation increases, compensation structures and compensation scales. Compensation includes direct cash payments, indirect payments in the form of employee benefits, and incentives to motivate employees to work hard to achieve higher productivity. If managed properly, then with this compensation can help companies to achieve higher productivity for their employees. Conversely, if there is not enough compensation, then the employee will be very likely for them to leave the company and to do the placement again is not easy. This compensation is intended as a remuneration for the company to sacrifice the time, effort and thought that they have given to the company.

Compensation can be defined as any form of award given to employees as remuneration for the contributions they give to the organization (Torang, 2013). According to Notoatmodjo (2009) suggests that compensation is calculated based on job evaluation, the calculation of compensation based on the evaluation of the work is intended to get compensation that is close to feasibility and fairness. Because if compensation is felt to be inappropriate and unfair by employees, it is not impossible that it is a source of social jealousy. Whereas according to Handoko (2013) what is meant by compensation is everything that is received by employees as remuneration for their work.

Compensation can be given in various forms such as in the form of giving money, giving materials and facilities, and in the form of providing career opportunities. According to Sunyoto, (2012) compensation is the overall remuneration received by employees as a result of the implementation of work in the organization in the form of money or other, which can be in the form of salaries, wages, bonuses, incentives and health benefits, holiday allowances, meal money, money leave and others. The above payments are directly related to performance such as wages or salaries, bonuses and commissions so that they are often called direct 
compensation and some are not directly related to performance in an effort to improve employee calm and job satisfaction such as benefits.

Notoatmodjo (2009) suggests there are several factors that influence compensation giving, namely:

1) Productivity. Compensation looks at the amount of productivity contributed by employees to the company.

2) Ability to pay. Logically the size of compensation is highly dependent on the company's ability to pay employee compensation.

3) Willingness to pay. Even though the company is able to pay compensation, the company is not necessarily willing to pay the compensation properly and fairly.

4) Supply and demand for labor. Supply and demand for labor are quite influential on the provision of compensation.

\section{Work Culture}

Work culture is a group of behavioral patterns that are inherent in all individuals in an organization. Building culture also means enhancing and maintaining positive sides, and trying to familiarize certain patterns of behavior in order to create a better new form. The notion of work culture according to Nawawi (2003) explains that work culture is a habit that is carried out repeatedly by employees in an organization, violations with this practice are indeed not explicit sanctions, but from organizational actors morally have agreed that these habits are habits that must be obeyed in order to carry out the work to achieve the goal. Work culture is behavior carried out repeatedly by each individual in an organization and has become a habit in carrying out work.

According to Triguno (2001), it explains that, work culture is a philosophy based on the view of life as values that become traits, habits, and driving forces, entrenched in the life of a community group or organization that are reflected in attitudes, beliefs, ideals, opinions and actions that materialize as work or work. According to Robbins \& Judge (2007: 51) organizational culture is the values, principles, traditions, and attitudes that influence the way in which members of the organization act. According to Robbins \& Judge (2007: 52), there are 7 dimensions of organizational culture, namely:

1. Innovation and courage to take risks is the extent to which organizations encourage employees to be innovative and take risks. In addition, how organizations value the actions of risk taking by employees and generate employee ideas.

2. Attention to detail is the extent to which the organization expects employees to show accuracy, analysis and attention to details.

3. Results oriented is the extent to which management focuses on results rather than attention to the techniques and processes used to achieve this.

4. Oriented to humans is the extent to which management decisions take into account the effects of results on people in the organization.

5. Team oriented is the extent to which work activities are organized by teams, not individuals.

6. Aggressive attitude is the extent to which people in the organization are aggressive and competitive to run the best organizational culture.

7. Stability is the extent to which an organization's activities emphasize the status quo (maintaining what is there because it is considered good enough) rather than growth. 
The work culture indicators according to Ndraha (2005) can be categorized as three, namely:

\section{1) Habits}

Habits can usually be seen from how to form employee organizational behavior, namely behavior based on awareness of the rights and obligations, freedom or authority and responsibilities of both individuals and groups within the scope of the work environment. As for other terms that can be considered stronger than attitudes, namely the establishment, if the attitude can change its position is expected not based on determination or strength. Then it can be interpreted that the attitude is a mirror of behavior patterns or attitudes that are often carried out either in a conscious state or in a state of unconsciousness, habits are usually difficult to repair quickly due to the nature of being born, but can be overcome by the existence of strict rules from organization or company.

\section{2) Regulations}

To provide order and comfort in carrying out the work duties of employees, it is necessary to have regulations because regulations are a form of firmness and the most important part is to realize disciplined employees in complying with all forms of applicable regulations.

\section{3) Values}

Value is a person's appreciation of what is more important or less important, what is better or less good, and what is more true or less true. To be able to play a value must reveal themselves through certain media. Values are abstract, can only be observed or felt if recorded or contained in a vehicle or work culture. So the value and work culture cannot be separated and both must have harmony with the work culture in the same direction, harmony and balance. Assessment is felt to be very important to provide an evaluation of the performance of employees so that they can provide value both in quality and quantity.

Work culture has the purpose of changing attitudes and behavior of existing human resources in order to increase work productivity to face various challenges in the future. Benefits of implementing a good work culture:

1. Increase the spirit of mutual cooperation

2. Increase togetherness

3. Open one another

4. Increase family spirit

5. Increase the sense of family

6. Build better communication

7. Increase work productivity

8. Considered by the development of the outside world.

So the benefits of a good work culture will bring good changes in achieving the desired results of the leadership such as mutual cooperation, togetherness, openness, family and also work productivity in completing the work given to each member of the organization.

\section{Job Satisfaction}

Job satisfaction is a pleasant or unpleasant emotional state with which the aryawan view their work (Handoko, 2013). Job satisfaction reflects a person's feelings for their work. This appears in a positive attitude towards work and everything that is faced in his work environment. Mangkunegara (2002: 117) defines job satisfaction as a feeling that supports or does not support employees who are related to their employment or their condition. Whereas according to Simamora (2005: 65) states that job satisfaction is a set of employee feelings about fun or not their work. 
According to Robbins (2002: 78) job satisfaction is a general attitude towards someone's work that shows the difference between the number of awards received and the amount they believe they should receive. According to Vecchio (1995: 124) states job satisfaction as thoughts, feelings, and tendencies of one's actions which is a person's attitude towards work. Based on the opinions of experts regarding job satisfaction, it can be concluded that job satisfaction is an expression of one's feelings for their work, either in the form of pleasant or unpleasant esoteric conditions, expected and accepted rewards and employee attitudes towards their work and condition.

According to Robbins (2002: 101) there are two approaches that can be used to measure employee job satisfaction, including:

\section{Single global value}

Where to ask individuals to answer one question, for example "how satisfied are you with your job?" Then the respondent answers by circling a number between 1-5 who thinks with answers from "very satisfied" to "very dissatisfied"

\section{Addition score}

Where to recognize the main elements in a job and ask employees how they feel about each element. Factors that can be used are the nature of work, supervision, current wages, promotion opportunities and relationships with co-workers. This factor is assessed on a standard scale and then added to create an overall job satisfaction score.

According to Gelluci (1978) states that there are several indicators to measure job satisfaction, including:

1. Satisfaction with salary

2. Satisfaction with promotions

3. Satisfaction with coworkers

4. Satisfaction with supervisors

5. Satisfaction with work

\section{Performance}

The concept of performance can be defined as the level of achievement of results. Performance is the result of a series of process activities carried out to achieve certain goals of an organization. Performance assessment is very important because it can be used as a measure of the success of an organization in achieving its objectives. According to Keban (2004) performance is a translation of "performance" which is often interpreted as appearance, demonstration or achievement. Performance is the level of achievement of organizational goals on an ongoing basis, whereas according to Mahsun (2006) performance is a description of the level of achievement of a program, activity or policy in realizing the goals, objectives, mission, and vision of the organization contained in an organization's strategic plan.

From some of the opinions above, then the concept of a performance is a description of the achievement of individuals or groups in an organization in the implementation of activities, programs, and policies to realize the vision, mission, and organizational goals determined by organizational performance. the purpose of which is influenced by the resources possessed by the organization. In an organization, performance appraisal of the organization is important. This is because between performance and performance appraisal is an inseparable thing, as revealed by Fadel (2009: 195) states that there are several types of indicators that can be used in implementing organizational performance measurements, and researchers use to measure the performance of the Fire and Rescue Service Kota Sungai Penuh is as follows: 
1. Understanding of tupoksi, in carrying out tupoksi, subordinates must first understand the main tasks and functions of each and work on tasks in accordance with what is their responsibility.

2. Speed of work, in carrying out the task of work speed must be considered by following the existing work methods.

3. Work accuracy, not only fast but in doing the work, employees must also be disciplined in doing the assignments carefully, in working and checking the results of the work again.

4. Collaboration in working with coworkers and can accept opinions and respect others.

From the various opinions above, it can be concluded that there are many factors that influence the level of performance in an organization. But broadly speaking, the very dominant factors affecting organizational performance are internal factors (factors that come from within the organization) and external factors (factors that come from outside the organization). Each organization will have different levels of performance because in essence each organization has its own characteristics or characteristics so that the problems faced also tend to be different depending on internal and external factors of the organization.

\section{RESEACH LOCATION}

The research was conducted by the Sungai Penuh City Fire and Rescue Service from JulyOctober 2018, where the main task of the fire department carried out some regional authority in the field of fire prevention and prevention which included prevention, guidance and counseling, operational control. While the function of the Sungai Penuh City Fire and Rescue Service is to formulate technical policies in the field of fire prevention and mitigation, carry out operational technical duties in the field of fire prevention and control and carry out administrative technical services including general administration and staffing, planning and development and financial administration. The implementation of the Sungai Penuh City Fire and Rescue Service is regulated by the Regulations of the Mayor of Sungai Penuh and the Decision of the Head of the Fire Department and City River Rescue Service Full of Numbers. 364/1/001 / Disdamkar 2018 concerning the Establishment of Operational Staff at the Sungai Penuh City Fire and Rescue Service.

\section{Research Hypothesis}

Fire fighting organization is one form of service activities to the community in providing help of the soul and property that is demanded speed and accuracy in providing services, in the language of extinguishers known as the response time with approximately 15 minutes required or a maximum distance of $7.5 \mathrm{KM}$ from the fire station. Therefore the Fire and Rescue Service is required to be able to work with good performance. Where performance is a picture of achievement by individuals or groups in an organization in the implementation of activities, programs, and policies in order to realize the vision, mission, and organizational goals that are determined organizational performance is a picture of the work of an organization in achieving its objectives that are influenced by resources owned by the organization. Thus the conceptual framework in this study can be seen in the following figure: 


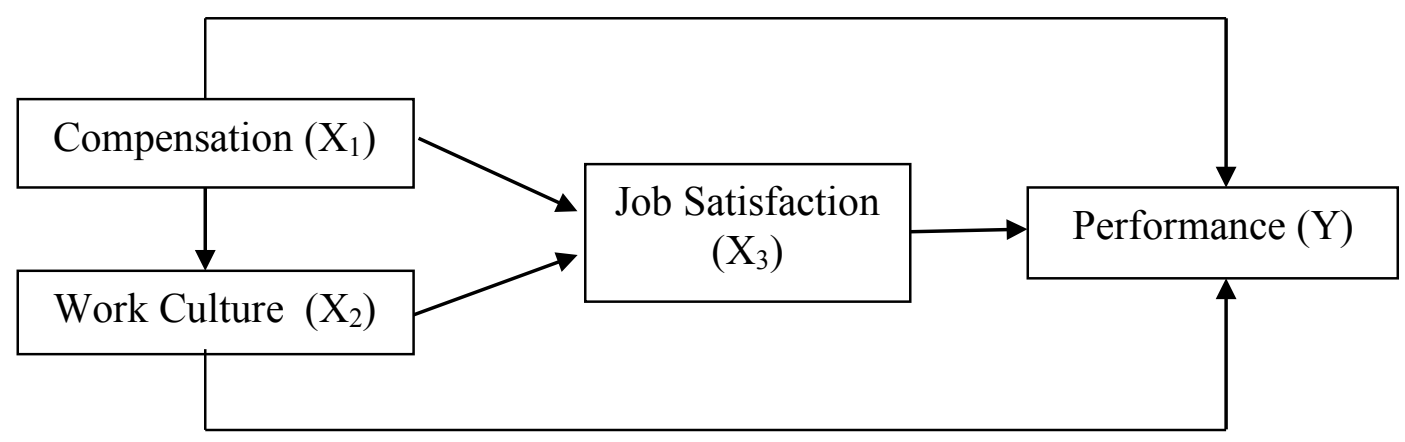

Figure 1: Conceptual Framework

Referring to the conceptual framework above, the research hypothesis can be developed as follows:

1. Compensation affects the work culture of the Sungai Penuh City Fire and Rescue Service organization.

2. Compensation affects the job satisfaction of the Sungai Penuh City Fire and Rescue Service organization.

3. Work culture affects the job satisfaction of the Sungai Penuh City Fire and Rescue Service organization.

4. Job satisfaction affects the performance of the Sungai Penuh City Fire and Rescue Service organization.

5. Compensation affects the performance of the Sungai Penuh City Fire and Rescue Service organization.

6. Work culture affects the performance of the Sungai Penuh City Fire and Rescue Service organization.

7. Compensation and work culture affect performance which is mediated by job satisfaction at the Sungai Penuh City Fire and Rescue Service.

\section{Research Context}

\section{RESEARCH METHODOLOGY}

Based on the formulation and research objectives, this type of research is quantitative research where research is conducted to find out or connect between variables one with other variables (Sugiyono, 2007). In this study the researchers wanted to see the effect of compensation and work culture and job satisfaction on the performance of the Sungai Penuh City Fire and Rescue Service organization.

\section{Measurement and Research Instruments}

To facilitate the implementation of the study it is necessary to define and measure the variables to be examined as the basis for the preparation of questionnaires and interview guidelines. Variables are an attribute of the group of objects studied which have variations between one another in the group (Sugiyono, 2007). 
Tabel 1: Reseach Variable

\begin{tabular}{|c|c|c|c|c|c|}
\hline No & Variable & Variable definition & Indicator & Source & Item \\
\hline 1 & $\begin{array}{l}\text { Compensation } \\
\left(\mathrm{X}_{1}\right)\end{array}$ & $\begin{array}{l}\text { Compensation can be defined as any } \\
\text { form of award given to employees as a } \\
\text { reward for the contribution they make to } \\
\text { the organization }\end{array}$ & $\begin{array}{l}\text { 1. Salary } \\
\text { 2. Incentives } \\
\text { 3. Bonus } \\
\text { 4. Health insurance }\end{array}$ & $\begin{array}{l}\text { Hasim } \\
\text { Umar } \\
(2007)\end{array}$ & 15 item \\
\hline 2 & $\begin{array}{l}\text { Work Culture } \\
\left(X_{2}\right)\end{array}$ & $\begin{array}{l}\text { The habit that is repeatedly carried out } \\
\text { by employees in an organization, } \\
\text { violation of this habit does not have a } \\
\text { strict sanction, but from an } \\
\text { organizational actor morally has agreed } \\
\text { that the habit is a habit that must be } \\
\text { adhered to in the course of carrying out } \\
\text { work to achieve goals }\end{array}$ & $\begin{array}{l}\text { 1. Innovation and } \\
\quad \text { courage to take risks. } \\
\text { 2. Result oriented. } \\
\text { 3. Team oriented } \\
\text { 4. Attention }\end{array}$ & $\begin{array}{l}\text { Robbins } \\
\text { \&Judge } \\
(2007: 51)\end{array}$ & 11 item \\
\hline 3 & $\begin{array}{l}\text { Job Satisfaction } \\
\left(\mathrm{X}_{3}\right)\end{array}$ & $\begin{array}{l}\text { Job satisfaction is a feeling of happiness } \\
\text { and unpleasantness of employees at the } \\
\text { Sungai Penuh City Fire and Rescue } \\
\text { Service }\end{array}$ & $\begin{array}{l}\text { 1. Satisfaction with } \\
\text { salary } \\
\text { 2. Satisfaction with } \\
\text { promotions. } \\
\text { 3. Satisfaction with } \\
\text { coworkers. } \\
\text { 4. Satisfaction with } \\
\text { supervisors. } \\
\text { 5. Job satisfaction }\end{array}$ & $\begin{array}{l}\text { Celluci } \\
\text { Anthony J } \\
\text { dan David } \\
\text { L De Vries } \\
\text { (1978) }\end{array}$ & 13 item \\
\hline 4 & $\begin{array}{l}\text { Performance } \\
\text { (Y) }\end{array}$ & $\begin{array}{l}\text { Performance is the result of a series of } \\
\text { process activities carried out to achieve } \\
\text { certain goals of an organization }\end{array}$ & $\begin{array}{l}\text { 1. Understanding of } \\
\text { tupoksi } \\
\text { 2. Speed of work } \\
\text { 3. Work accuracy } \\
\text { 4. Cooperation }\end{array}$ & $\begin{array}{l}\text { Fadel } \\
(2009: 19)\end{array}$ & 12 item \\
\hline
\end{tabular}

In this study instrument measurements were carried out using a Likert Scale. Likert scale is used to measure attitudes, opinions, perceptions of a person or group of people about social phenomena (Sugiyo, 2008). The size of the research variables can be seen in the table of measurement of research variables with the following Likert Scale:

Table 2: Research Variable Measurement

\begin{tabular}{|c|l|c|}
\hline No. & Answer Category & Score \\
\hline 1 & Strongly Agree & 5 \\
\hline 2 & Agree & 4 \\
\hline 3 & Neutral & 3 \\
\hline 4 & Not Agree & 2 \\
\hline 5 & Strongly Disagree & 1 \\
\hline
\end{tabular}

\section{Pengumpulan Data dan Sampel}

Questionnaire is a technique of data collection conducted by giving a set of questions or written statements to the respondent to answer. In this study there are two types of data used, namely primary and secondary data. The sample is part of the number and characteristics of the population. The sampling technique in this study using probability sampling techniques is a sampling technique that provides equal opportunities for each member of the population to be selected as a sample. The method of sampling using random sampling is a technique of determining samples from a population carried out randomly regardless of the strata that exist in the population.

Taking the number of samples in this study using the Slovin formula, namely:

$$
n=\frac{N}{1+N e^{2}}
$$


Information:

$\mathrm{n}=$ Number of samples

$\mathrm{N}=$ Number of population

$\mathrm{e}=$ Error tolerance taken by researchers (5\% Error Rate)

Based on the Slovin formula, the sample used in this study, namely

$$
\begin{aligned}
n & =\frac{273}{1+273 \times 0,05^{2}} \\
& =162
\end{aligned}
$$

Thus the sample used in this study was 162 operational staff of the Sungai Penuh City Fire and Rescue Service.

\section{Descriptive Profile of Respondents}

\section{ANALYSIS OF RESEARCH RESULTS}

Based on the table above it can be seen that the most respondents in this study were aged 2030 years with a percentage of $41.35 \%$ and at least 40 years old with a percentage of $22.83 \%$. The highest number of respondents in this study had a high school education level with a percentage of $92.59 \%$ and the least had a graduate education level with a percentage of $1.23 \%$. The most respondents in this study had a 1-year work period with a percentage of $53.70 \%$ and the least had a work period of less than one year with a percentage of $15.43 \%$.

Table 3: Research Variable Measurement

\begin{tabular}{|l|l|l|}
\hline Age & Frequency & Percentage \\
\hline 20 -30 years & 67 & $41,25 \%$ \\
\hline 30 - 40 years & 58 & $35,80 \%$ \\
\hline 40 year & 37 & $22,83 \%$ \\
\hline Education & Frequency & Percentage \\
\hline junior high school & 8 & $4,93 \%$ \\
\hline senior High School & 150 & $92,59 \%$ \\
\hline bachelor & 2 & $1,23 \%$ \\
\hline Years of service & Frequency & Percentage \\
\hline < fromi 1 year & 25 & $15,43 \%$ \\
\hline 1 Year & 87 & $53,70 \%$ \\
\hline$>$ from 2 years & 50 & $30,86 \%$ \\
\hline
\end{tabular}

\section{Validity test}

An instrument is said to be valid if it is able to measure what is desired and can reveal data from the variables under study. To find out the validity of the instrument used, the validity test (using the SPSS statistical program) was carried out by comparing the corrected item values the total correlation with the $r$ spearmen table at $\alpha=0.05$ (for $\mathrm{N}=162$, $\mathrm{r}$ table $=0.30$ ) with provisions if $r>0.30$ means valid, but if the significance value $r<0.30$ means the instrument is declared invalid. Validity tests on compensation variables with a number of 15 questions, work culture variables with number of questions 11 , job satisfaction variables with number 13 questions and performance variables with number 12 questions indicate that all items related to compensation are in valid status.

\section{Reliability Test}

Based on the data in the table below, the coefficient of alpha count for each research variable shows a value greater than the $r$ table value $(0.60)$. This means that all questions in the research variables are declared reliable and have consistency. 
Table 4: Reliability Test

\begin{tabular}{|c|c|c|c|}
\hline Variable & $\begin{array}{c}\text { Coefficient } \\
\text { Alpha Count }\end{array}$ & Criteria & Status \\
\hline Compensation & 0,652 & 0,60 & Reliable \\
Work Culture & 0,895 & 0,60 & Reliable \\
Job Satisfaction & 0,684 & 0,60 & Reliable \\
Performance & 0,781 & 0,60 & Reliable \\
\hline
\end{tabular}

\section{Descriptive Analysis}

This analysis intends to describe the characteristics of each research variable. Based on the data in the table above, it can be seen the level of achievement of the research variable starting from the compensation variable with the achievement level of $78.41 \%$, so it can be concluded that compensation is in a fairly good category. Work culture variables with achievement levels of $80.07 \%$ can be concluded to be in the good category. Job satisfaction variable with achievement rate of $80.97 \%$ can be concluded to be in the good category. Performance variables with a performance level of $79.95 \%$ can be concluded to be in a fairly good category.

Table 5: Descriptive Analysis

\begin{tabular}{|c|c|c|}
\hline Variable & TCR & Category \\
\hline Compensation & 78,41 & Fairly good \\
\hline Work Culture & 80,07 & Good \\
\hline Job Satisfaction & 80,97 & Good \\
\hline Performance & 79,95 & Fairly good \\
\hline
\end{tabular}

\section{Multicollinearity Test}

Before doing multiple regression analysis, the multicollinearity test was first carried out. The absence of multicollinearity or the absence of a high linear relationship between independent variables.

Table 6: Multicollinearity Test

\begin{tabular}{|ll|c|c|}
\hline \multirow{2}{*}{\multicolumn{2}{|c|}{ Model }} & \multicolumn{2}{c|}{ Collinearity Statistics } \\
\cline { 2 - 3 } & Tolerance & VIF \\
\hline $1 \quad$ (Constant) & & \\
& Compensation $\left(\mathrm{X}_{1}\right)$ & .994 & 1.006 \\
& Work Culture $\left(\mathrm{X}_{2}\right)$ & .998 & 1.002 \\
& Job Satisfaction $\left(\mathrm{X}_{3}\right)$ & .996 & 1.004 \\
\hline
\end{tabular}

With Multicollinearity testing above, it can be seen that the VIF (variance Inflation Factor) values of all variables (X1, X2, X3) $<5$ can therefore be concluded that there is no strong correlation between the independent variables.

\section{Heteroscedasticity Test}

From the heteroscedasticity test below, it can be seen that the significance values of each variable $(\mathrm{X} 1, \mathrm{X} 2$ and $\mathrm{X} 3)>\alpha=0.05$. Therefore it can be concluded that there were no heterocedasticity problems in this study. Thus it can be said that there is no relationship between independent variables with error terms. 
Table 7: Heteroscedasticity Test

\begin{tabular}{|c|c|c|c|c|c|}
\hline \multirow[b]{2}{*}{ Model } & \multicolumn{2}{|c|}{$\begin{array}{l}\text { Unstandardized } \\
\text { Coefficients }\end{array}$} & \multirow{2}{*}{$\begin{array}{c}\text { Standardized } \\
\text { Coefficients } \\
\text { Beta } \\
\end{array}$} & \multirow[b]{2}{*}{$\mathrm{t}$} & \multirow[b]{2}{*}{ Sig. } \\
\hline & $\mathrm{B}$ & $\begin{array}{l}\text { Std. } \\
\text { Error }\end{array}$ & & & \\
\hline $1 \quad$ (Constant) & .223 & 3.501 & & .064 & .949 \\
\hline Compensation $\left(\mathrm{X}_{1}\right)$ & .009 & .034 & .022 & .273 & .785 \\
\hline Work Culture $\left(\mathrm{X}_{2}\right)$ & .074 & .046 & .128 & 1.624 & .106 \\
\hline Job Satisfaction $\left(\mathrm{X}_{3}\right)$ & -.024 & .043 & -.044 & -.561 & .576 \\
\hline
\end{tabular}

\section{Path Analysis}

Based on the table below the regression equation is known to be a constant of 42,140 which means that without the Compensation variable (X1), the Work Culture of the Sungai Penuh City Fire and Rescue Service employees is 42,140 . The results of the analysis of the influence of the Compensation variable (X1) on the Employee Work Culture (X2) with a significance level of $0.583>0.05$.

Table 8: Test Substructure 1

\begin{tabular}{|c|c|c|c|c|c|}
\hline \multirow[b]{2}{*}{ Model } & \multicolumn{2}{|c|}{ Unstandardized Coefficients } & \multirow{2}{*}{$\begin{array}{c}\text { Standardized } \\
\text { Coefficients } \\
\text { Beta } \\
\end{array}$} & \multirow[b]{2}{*}{$\mathrm{t}$} & \multirow[b]{2}{*}{ Sig. } \\
\hline & B & Std. Error & & & \\
\hline $1 \quad$ (Constant) & 42.140 & 3.426 & & 12.299 & .000 \\
\hline Compensation & .032 & .058 & .043 & .550 & .583 \\
\hline
\end{tabular}

Futhermore the results of the analysis showed that there was no significant effect of compensation on the work culture of the Sungai Penuh City Fire and Rescue Service.

Table 9: Test Substructure 2

\begin{tabular}{|c|c|c|c|c|c|c|}
\hline \multirow{2}{*}{\multicolumn{2}{|c|}{ Model }} & \multicolumn{2}{|c|}{ Unstandardized Coefficients } & \multirow{2}{*}{\begin{tabular}{|c}
$\begin{array}{c}\text { Standardized } \\
\text { Coefficients }\end{array}$ \\
Beta
\end{tabular}} & \multirow[b]{2}{*}{$\mathrm{T}$} & \multirow[b]{2}{*}{ Sig. } \\
\hline & & $\mathrm{B}$ & Std. Error & & & \\
\hline 1 & (Constant) & 50.004 & 5.065 & & 9.872 & .000 \\
\hline & Compensation & .050 & .062 & .064 & .806 & .000 \\
\hline & $\begin{array}{l}\text { Work } \\
\text { Culture }\end{array}$ & .007 & .084 & .006 & .078 & .000 \\
\hline
\end{tabular}

Based on the data in the table above the influence of each variable consisting of the Compensation variable (X1), Work Culture (X2) on the Job Satisfaction variable (X3) is as follows:

1. Effect of Compensation (X1) on Job Satisfaction (X3) The Sungai Penuh City Fire and Rescue Service is positive at 0.050 with a t count of 0.806 (Sig $0,000<0.05$ ), indicating that Compensation has a significant effect on job satisfaction of the Fire Department and Rescue of Sungai Penuh City.

2. Effect of Work Culture (X2) on Job Satisfaction (X3) The Sungai Penuh City Fire and Rescue Service is positive at 0.007 with t count of 0.078 (Sig 0,000<0.05), indicating that Work Culture has a significant effect on Service job satisfaction Fire and Rescue of Sungai Penuh City. 
So Compensation (X1) and Work Culture (X2) have a positive and significant effect on Job Satisfaction (X3) of the Sungai Penuh City Fire and Rescue Service.

Table 10: Test Substructure 3

\begin{tabular}{|c|c|c|c|c|c|c|}
\hline \multirow{2}{*}{\multicolumn{2}{|c|}{ Model }} & \multicolumn{2}{|c|}{ Unstandardized Coefficiets } & \multirow{2}{*}{$\begin{array}{c}\begin{array}{c}\text { Standardized } \\
\text { Coefficients }\end{array} \\
\text { Beta }\end{array}$} & \multirow[b]{2}{*}{$\mathrm{T}$} & \multirow[b]{2}{*}{ Sig. } \\
\hline & & $\mathrm{B}$ & Std. Error & & & \\
\hline \multirow[t]{4}{*}{1} & (Constant) & 45.436 & 5.775 & & 7.867 & .000 \\
\hline & Compensation & .103 & .055 & .147 & 1.860 & .001 \\
\hline & Work Culture & .034 & .075 & .036 & .452 & .000 \\
\hline & Job Satisfaction & .038 & .071 & .043 & .540 & .003 \\
\hline
\end{tabular}

Based on the data in the table above the influence of each variable consisting of the variable Compensation (X1), Work Culture (X2) Job Satisfaction (X3) on Performance (Y) are as follows:

1. Effect of Compensation (X1) on Performance (Y) The Sungai Penuh City Fire and Rescue Service is positive at 0.103 with a t count value of 1.860 (Sig $0.001<0.05$ ), indicating that Compensation has a significant effect on the Performance of the Fire and Rescue Service Kota Sungai Penuh.

2. Effect of Work Culture (X2) on Performance (Y) The Sungai Penuh City Fire and Rescue Service is positive at 0.034 with $t$ count 0.452 (Sig $0,000<0.05$ ), indicating that the Work Culture has a significant effect on the Performance of the Fire Department and Rescue of Sungai Penuh City.

3. Effect of Job Satisfaction (X3) on Performance (Y) The Sungai Penuh City Fire and Rescue Service is positive at 0.038 with a t count of 0.540 (Sig $0.003<0.05$ ), indicating that Job Satisfaction has a significant effect on Fire Department Performance and Rescue of Sungai Penuh City.

So Compensation (X1), Work Culture (X2) and Job Satisfaction (X3) have a positive and significant effect on Performance (Y) of the Sungai Penuh City Fire and Rescue Service.

\section{t test}

The statistical $t$ test is used to test the effect of each independent variable on the dependent variable. The reference used is if the significance value ( $\mathrm{Sig}<0.05$ ), it can be concluded that the independent variable path coefficient is significant.

Table 11: t test

\begin{tabular}{|c|c|c|}
\hline Variable & T count & Sig.t \\
\hline $\mathrm{X}_{1} \longrightarrow \mathrm{X}_{2}$ & .550 & .583 \\
\hline $\mathrm{X}_{1} \longrightarrow \mathrm{X}_{3}$ & .806 & .000 \\
\hline $\mathrm{X}_{2} \longrightarrow \mathrm{X}_{3}$ & .078 & .000 \\
\hline $\mathrm{X}_{1} \longrightarrow \mathrm{Y}$ & 1.860 & .001 \\
\hline $\mathrm{X}_{2} \longrightarrow \mathrm{Y}$ & .452 & .000 \\
\hline $\mathrm{X}_{3} \longrightarrow \mathrm{Y}$ & .540 & .003 \\
\hline
\end{tabular}

The results of the analysis can be drawn conclusions for the assessment hypothesis as follows: The first hypothesis proposed is Compensation (X1) which has a significant effect on Work Culture (X2). From the SPSS output above the value of t count X1 against X2 $=0.550$ while the Sig value is $0.583>0.05$, there is no significant influence between the Compensation variable (X1) on Work Culture (X2). Thus it can be concluded that compensation does not have a significant effect on the Work Culture of the Sungai Penuh City Fire and Rescue Service. 
The second hypothesis proposed is Compensation (X1) which has a significant effect on Job Satisfaction (X3). From the SPSS output above the value of t count X1 against X3 $=0.806$ while the Sig value is $0,000<0.05$, there is a significant influence between the variable Compensation (X1) on Job Satisfaction (X3). Thus it can be concluded that compensation has a significant effect on Job Satisfaction of the Sungai Penuh City Fire and Rescue Service.

The third hypothesis proposed is Work Culture (X2) which has a significant effect on Job Satisfaction (X3). From the SPSS output above the value of $t$ count X2 against X3 $=0.078$ while the Sig value is $0,000<0,05$, there is a significant influence between the Work Culture variable (X2) on Job Satisfaction (X3). Thus it can be concluded that the Work Culture has a significant effect on the job satisfaction of the Sungai Penuh City Fire and Rescue Service.

The fourth hypothesis proposed is Compensation (X1) which has a significant effect on Performance (Y). From the SPSS output above the value of t count X1 against $Y=1.860$ while the Sig value is $0.001<0.05$, there is a significant influence between the variable Compensation (X1) on Performance (Y). Thus it can be concluded that compensation has a significant effect on the performance of the Sungai Penuh City Fire and Rescue Service.

The fifth hypothesis proposed is Work Culture (X2) that has a significant effect on Performance $(\mathrm{Y})$. From the SPSS output above the value of $\mathrm{t}$ count $\mathrm{X} 2$ to $\mathrm{Y}=0.452$ while the Sig value is $0,000<0.05$, there is a significant influence between the variable Work Culture (X2) on Performance (Y). Thus it can be concluded that the Work Culture has a significant effect on the Performance of the Sungai Penuh City Fire and Rescue Service.

The Sixth Hypothesis proposed is Job Satisfaction (X3) which has a significant effect on Performance (Y). From the SPSS output above the value of t count X3 to Y $=0.540$ while the Sig value is $0.003<0.05$, there is a significant effect between the variables of Job Satisfaction (X3) on Performance (Y). Thus it can be concluded that Job Satisfaction has a significant effect on the Performance of the Sungai Penuh City Fire and Rescue Service.

The Seventh Hypothesis proposed namely Compensation (X1) and Work Culture (X2) mediated by Job Satisfaction (X3) has a significant effect on Performance (Y). It is known that the direct effect given by Compensation (X1) on Job Satisfaction (X3) is 0.064 while the direct effect of variable Work Culture (X2) on Job Satisfaction (X3) is 0.006 and the direct effect of Job Satisfaction (X3) on Performance (Y) is 0.043 , then the indirect effect of variables (X1) and (X2) through (X3) on (Y) is $0.064 \times 0.006 \times 0.043=0.00002$, the total influence given by variables $(\mathrm{X} 1)$ and $(\mathrm{X} 2)$ through $(\mathrm{X} 3)$ to $(\mathrm{Y})$ is $0.147+0.036+0.00002=0.183$. From the SPSS output above the value of $t$ count towards $Y=7.867$ while the Sig value is $0,000<0.05$, there is a significant influence between the Compensation variable (X1) and Work Culture (X2) mediated by Job Satisfaction (X3) on Performance (Y). Thus it can be concluded that Compensation and Work Culture mediated by Job Satisfaction have a significant effect on the Performance of the Sungai Penuh City Fire and Rescue Service.

\section{F test}

The $\mathrm{F}$ test was conducted to determine whether all the independent variables namely, Compensation (X1), Work Culture (X2) and Job Satisfaction (X3) together had a significant effect on the dependent variable of the Sungai Penuh City Fire and Rescue Service Performance. 
Table 12: F test

\begin{tabular}{|ll|c|c|c|c|c|}
\hline Model & & Sum of Squares & $\mathrm{df}$ & Mean Square & $\mathrm{F}$ & Sig. \\
\hline 1 & Regression & 46.777 & 3 & 15.592 & 8.476 & $.000^{\mathrm{a}}$ \\
& Residual & 1957.124 & 158 & 12.387 & & \\
& Total & 2003.901 & 161 & & & \\
\hline
\end{tabular}

From the table above, it can be seen that the $\mathrm{F}$ count is 8,476 and the significance is 0,000 , the significance value $(0,000<0,05)$. This shows that the significance value is smaller than 0.005 , which means that $\mathrm{HO}$ is rejected and Ha is accepted. In other words, Compensation (X1), Work Culture (X2) and Job Satisfaction (X3) together have a significant effect on the dependent variable of the Sungai Penuh City Fire and Rescue Service (Y).

\section{Theoretical Contributions}

\section{DISCUSSION AND CONCLUSION}

From the results of the data analysis, it is known that the Compensation variable (X1) does not have a significant effect on Work Culture (X2), the Sungai Penuh City Fire and Rescue Service. This is because based on the results of testing of the respondents' answers, it shows the results that the compensation from the Sungai Penuh City Fire and Rescue Service does not affect the work culture of operational personnel. This is because, work culture is a behavior and values that are embedded in an organization. The Sungai Penuh City Fire and Rescue Service is one of the agencies that requires employees to be disciplined and alert in all conditions, because the work carried out by employees of the Sungai Penuh City Fire and Rescue Service concerns saving human lives in the event of a fire.

From the results of data analysis it is known that the Compensation variable (X1) has a significant effect on Job Satisfaction (X3) of the Sungai Penuh City Fire and Rescue Service. This is because based on the results of testing of respondents' answers, the results show that Compensation from the Sungai Penuh City Fire and Rescue Service has an effect on job satisfaction of operational staff, thus it can be said that there is a significant influence between the Compensation variable on Job Satisfaction of the City Fire and Rescue Service Sungai Penuh. Compensation is calculated based on job evaluation, compensation calculations based on job evaluation are intended to get compensation that is close to feasibility and fairness. Because if compensation is perceived as inappropriate and unfair by employees, it is not impossible that it is a source of social jealousy (Notoatmodjo, 2009).

The work culture of the Sungai Penuh City Fire and Rescue Service influences the work satisfaction of operational staff, thus it can be said that there is a significant influence between the variables of Compensation on Job Satisfaction of the Sungai Penuh City Fire and Rescue Service. According to Triguno (2001), it explains that work culture is a philosophy based on life views as values that become traits, habits, and driving forces, entrenched in the life of a community group or organization, which are reflected in attitudes, beliefs, ideals ideals, opinions and actions that are realized as work. The work culture at the Sungai Penuh City Fire and Rescue Service can be said to be semi-military because it requires operational personnel to always be disciplined in work, because work as an operational force involves saving human lives. Therefore, in the organization of the Fire and Rescue Service of Sungai Penuh City, it is known as the motto: Abstinence Before the Fire Extinguished.

Compensation from the Sungai Penuh City Fire and Rescue Service has an effect on the performance of operational personnel, thus it can be said that there is a significant influence 
between the Compensation variable on the Work Performance of the Sungai Penuh City Fire and Rescue Service. These results are in line with the research of Saharudin (2013), Widya (2016) and Hera (2017) who concluded that compensation variables affect performance. So the results of this study prove the effect of significant compensation on the performance of the Sungai Penuh City Fire and Rescue Service.

The Work Culture of the Sungai Penuh City Fire and Rescue Service influences the performance of operational personnel, thus it can be said that there is a significant influence between the Work Culture variable on the Work Performance of the Sungai Penuh City Fire and Rescue Service. According to Robbins \& Judge (2007: 51) organizational culture is the values, principles, traditions, and attitudes that influence the way in which members of the organization act. In the Sungai Sungai City Rescue and Rescue Service organization there are very strong disciplinary values within its members. In addition to supporting the implementation of the fire department and the rescue of Sungai Penuh City, operational staff were provided with fire fighting techniques to support the performance of the Sungai Penuh City Fire and Rescue Service, in addition to fostering a sense of kinship among firefighters.

Job Satisfaction from the Sungai Penuh City Fire and Rescue Service influences the performance of operational personnel, thus it can be said that there is a significant influence between Job Satisfaction variables on the Work Performance of the Sungai Penuh City Fire and Rescue Service. Job satisfaction is a pleasant or unpleasant emotional state with which employees view their work (Handoko, 2013). Job satisfaction reflects a person's feelings for their work. This appears in a positive attitude towards work and everything faced in his work environment. The results of this study are in harmony with the research of Hidayat (2017) and Kristianto (2012) which states that job satisfaction has a significant effect on performance.

Compensation and Work Culture on Performance mediated by Job Satisfaction have a significant effect. The performance of the operational staff of the Sungai Penuh City Fire and Rescue Service will increase if there is appropriate Compensation and a strong Work Culture at the Sungai Penuh City Fire and Rescue Service, then indirectly this will increase Job Satisfaction for operational staff in carrying out work as firefighters at the Sungai Penuh City Fire and Rescue Service.

\section{Managerial Implications}

The results of this study show some results, one of which is compensation does not have a significant effect on the work culture of the Sungai Penuh City Fire and Rescue Service. This shows that no matter how much compensation is given to the operational staff of the Kota Sungai Penuh Fire and Rescue Service, it will not change the existing organizational culture. The organizational culture of the Sungai Penuh City Fire and Rescue Service requires employees to have high loyalty and discipline in work or in other words semi-military because the work carried out by operational personnel is related to direct handling of fire suppression and rescue of people from fire hazards.

Other results show that compensation and work culture have a significant effect on job satisfaction. Where the work satisfaction of the operational staff of the Sungai Penuh City Fire and Rescue Service will increase if the compensation given to operational personnel is in accordance with the responsibilities of the work carried out. In addition, work management and the work environment that exist in agencies within the scope of work culture also affect the satisfaction of operational personnel in working at the Sungai Penuh City Fire and Rescue Service. 
And the results of this study reveal that compensation, work culture and job satisfaction have a significant effect on performance. In other words, if the Sungai Penuh City Fire and Rescue Service wants to improve the performance of operational personnel there are several things that must be considered such as providing compensation to operational personnel, organizational work culture and operational personnel satisfaction in carrying out work and responsibilities at the Sungai Penuh City Fire and Rescue Service.

\section{Reference}

Cellucci, Anthony J.David L. De Vries (1978). Measuring Managerial Satisfaction: A Manual for the MJSQ, Technical Report II (Center for Creative Leadership)

Fadel. (2009). Indikator - indikator yang Mengukur Kinerja Pegawai. Bandung: Alfabet.

Handoko. (2013),Manajemen;Edisi Kedua,Cetakan Ketigabelas,BPFE Yogyakarta Persada

Hera. (2017). Pengaruh Kompensasi terhadap Kinerja Pegawai Dinas Sosial dan Tenaga Kerja kota Banjar. Jurnal Ekonomi dan Bisnis. Vol.XI, No.1. 2017

Hidayat, (2017). Analisis Model Pengaruh Dimensi Kepuasan Kerja Terhadap Kinerja Karyawan Pada PT. Centralindo Medika. Universitas Wijaya Putra Surabaya.

Keban. Y. (2004). Enam Dimensi Strategis Administrasi Publik, Konsep Teori dan Isu. PT. Gava Media:Jakarta Kristianto. (2012). Pengaruh Kepuasan Kerja Terhadap Kinerja Karyawan Dengan KomitmenOrganisasional Sebagai Variabel Intervening (Studi Pada RSUD Tugurejo Semarang).Jurnal Bisnis dan Strategi. Vol.20 No.2 Tahun 2012

Mahsun. (2006). Pengukuran Kinerja Sektor Publik. Penerbit BPFE: Yogjakarta

Mangkunegara. (2009). Manajemen Sumberdaya Manusia Perusahaan. Bandung PT. Remaja Rosdakarya

Nawawi. H. (2003). Manajemen Sumber Daya Manusia, Cetakan kelima, Gajah Mada University Press, Yogyakarta Notoatmodjo.S. (2009). Pengembangan Sumber Daya Manusia. Jakarta: RinekaCipta

Robbins. (2002). Perilaku Organisasi, Konsep, Kontroversi, Aplikasi, Alih Bahasa oleh Adyana Pujasmaka. Jakarta. PT. Prenhalindo

Robbins. S. P. \& Judge. T. A. (2007). Perilaku Organisasi. Penerbit Salemba empat Jakarta

Saharuddin, (2013), Penyusunan Rencana Strategis (Renstra) Dalam Upaya Meningkatkan Kinerja MAN Yogyakarta I. Hasil Penelitian. Tesis Program Studi Magister Manajemen Fakultas Ekonomika Dan Bisnis Universitas Gadjah Mada

Simamora, (2005) Analisis Multivariat Pemasaran. Jakarta : Gramedia Pustaka Utama

Sugiyono. (2007). Metode Penelitian Kuantitatif Kualitatif dan R\&D. Bandung: Alfabeta

Sunyoto. D. (2012). Manajemen Sumber Daya Manusia.Yogyakarta : CAPS

Taliziduhu,Ndaraha. (2005). Teori Budaya Organisasi, Cetakan Pertama, PT. Rineka Cipta, Jakarta

Torang. S. (2013). Organisasi dan manajemen (Perilaku, Strukture, Budaya, \& Perubahan Organisasi).Bandung: Alfabeta

Triguno. (2001). Budaya Kerja Organisasi Pemerintah. Jakarta

Vecchio, Robert P. (1995). Organizational Behavior. Florida: The Dryden Press.

Widya. U. (2016). Pengaruh Kompensasi, Motivasi dan Komitmen Organisasi Terhadap Kinerja Karyawan bagian Akuntansi. Jurnal The Indonesian Acounting Review. Vol.3 No.2 